\title{
WHAT HERITAGE DOES AND DOES NOT DO TO IDENIITY: SOME ANSWERS FROM AN EIHNOGRAPHIC PERSPECTIVE
}

\author{
Eric Gable \\ University of Mary Washington - United States of America
}

\begin{abstract}
This paper explores how caretakers of slave-era heritage sites objectify and enact what Robert Bellah and his co-authors call "communities of memory" in a racially polarized United States and how the public interpret their efforts at creating what amounts to official history. It highlights the often-vexed encounter between those who are in charge of conveying public representations of slavery and race in the antebellum era in the United States and vernacular responses to such representations. It looks at Monticello, the home of Thomas Jefferson, which recently has made great efforts to make slaves prominent figures in the landscapes it reconstructs in on-site maps, tours, and literature. Of particular interest are the various ways that vernacular skepticism and cynicism about public portrayals continues to generate controversy at Monticello, and particularly at how the topic of erasure and invisibility remain enduring themes in the popular imagination of what public history is all about when such history focuses on slavery and race. By interrogating public skepticism about official portrayals of the past, the paper moves towards a performative approach to studying what heritage does to identity production rather than a representational approach. Among the identities that are produced at Monticello (and by extension other antebellum sites) are racial and oppositional identities.
\end{abstract}

Keywords: heritage, official history, performance, skepticism.

Resumo: Este artigo explora a maneira com que administradores de sites sobre o patrimônio de uma era de escravidão objetivam e atuam como aquilo que foi chamado de "comunidades de memória" por Robert Bellah et al. em um Estados Unidos racialmente polarizado, bem como o modo com que o público interpreta os seus esforços de criar o que venha a ser a história oficial. Salienta-se o encontro muitas vezes controverso entre aqueles que estão encarregados de divulgar representações públicas de escravidão e de raça no período anterior à Guerra Civil nos Estados Unidos com as respostas correntes a tais representações. O presente estudo volta seu olhar para Monticello, cidade natal de Thomas 
Jefferson, que recentemente tem feito um grande esforço para tornar os escravos figuras preeminentes nas paisagens que a cidade reconstrói em mapas de sítios históricos, no turismo e na literatura. É especialmente interessante analisar as diversas maneiras com que o ceticismo e o cinismo correntes acerca de retratos públicos continua a gerar uma controvérsia em Monticello, e em particular o modo com que a rasura e a invisibilidade permanecendo sendo temas na imaginação popular do que seja a história pública quando tal história enfoca a escravidão e a raça. Questionando o ceticismo público sobre retratos oficiais feitos no passado, este artigo oferece uma abordagem que se filia à teoria da performance $e$ não à das representações sociais; o artigo apresenta, assim, um estudo das conseqüências do patrimônio herança sobre a produção de identidade. Entre as identidades produzidas em Monticello (e por extensão em outros sítios do período anterior à Guerra Civil norte-americana) estão a identidade racial e as identidades em oposição.

Palavras-chave: ceticismo, história oficial, patrimônio, performance.

I would like to use some observations I have made over the past fifteen years at a restored plantation in the Southern United States to make a few comments on what heritage sites do and do not do regarding identity. Identity is a hard to pin down concept, used perhaps way too much, defined, perhaps way too little, but generally deployed to refer to that sense persons have that they belong - that, for example, they identify with nation and with a nation's authorities. Heritage sites, as I am using the term, include buildings, monuments and museums, not to mention all those scattered pieces of inhabited or once-inhabited landscape which governments have set aside all those objects governments or private civic organizations have managed to preserve and protect; all those traces of the past that typify the public places of modern nation-states everywhere (Blatti, 1987; Evans; Boswell, 1999; Karp; Kraemer; Lavine, 1992; Karp; Lavine, 1991; Sherman; Rogoff, 1994). Heritage (or "the past") on display for edification and enjoyment is the quintessential feature of modernity. By the same token, identity - having one, not having one - is a quintessential problem of modernity.

Both scholars who work at heritage sites and those who study them as cultural phenomena assume that heritage does something significant to the consciousnesses of those who visit such sites (Nanda, 2004; White 1997; 
Yelvington, 2002). Critics of heritage sites argue that heritage is a vehicle for the dissemination of "official history" that inculcates a misplaced patriotism while erasing or eliding a more nuanced (and therefore politically useful) understanding of the past. Celebrators of heritage sites argue that nations need collective identities or shared social memories for developing a better, more committed citizenry and that it is the job of the state to provide them (Kammen, 1997). Heritage shapes national identity by creating an "imagined community” (Anderson, 1991) or a "community of memory” (Bellah et. al., 1985; Lowenthal, 1985).

As such, both those who celebrate and critique such sites assume their significance. They stress their representational power. But, if we study heritage sites and museums as places of performance rather than as forms of representation, we might question both the sanguine and pessimistic views of what these sites do. After all, imagined communities are created from the bottom up, as the people who visit museums sometimes argue back at the messengers. Moreover, museums in democratic nation-states actively pursue their publics and occasionally cater to their desires because museums, like modern democracies, are premised on the willing participation of a citizenry. As a result the history they produce is a cacophonous outcome of contest and compromise; it is a product of negotiations among the (at times deeply divided) professional historians and the (often factionalized) public at large (Handler; Gable, 1997). Museums may be in the business of producing official history, but as the museum also tries to enact democracy, the history it makes is inherently messy (Kurin, 1997).

History museum's caretakers have a peculiar relationship with their public in this managed "regime of knowledge" (Bennet, 1995). They are, as Tony Bennett argues, at once gatekeepers, judging a public's comportment, and facilitators, encouraging a public's participation. Members of a public whose understanding of "the past" diverges too widely from the caretakers' own understanding might be dismissed on grounds of comportment because in the context of the creation of a managed community of memory these dissenters count as a kind of rabble. But caretakers might also feel compelled to conform to their public's rearranging of the past even when the public's understanding seems at odds with authoritative knowledge (Gable, 1997). In the United States and I would imagine elsewhere, because the people who manage history museums feel that they must make a democracy as much as represent its collective past, they are constantly monitoring their 
ongoing engagement with the public, testing, for example, whether the site has a representative or suitably diverse following or whether it seems to cater to one audience and not another (see Kurin, 1997). Arguments about what counts as "true" or "false" history reveal and even exacerbate troubling differences among communities of "experts" and the public they ostensibly serve and educate. Yet, professional historians and educated members of the public increasingly operate with a model of "history" in which history is not the past but a reflection of present day concerns and prejudices. It is also generally assumed that contradictory versions often coexist and reflect the concerns of different factions within the public institution (see Handler; Gable, 1997). A museum or heritage site that a "significant" segment of the public does not visit or a site that this public loudly criticizes for using the cloak of authority to hide "the truth" can come to be perceived by its caretakers as a failure and an embarrassment.

In recent years, at American slave-era heritage sites, black Americans have acted as such a public, pressuring such sites' caretakers to change the way slaves and slavery are incorporated into America's pedagogic landscape (Horton; Crew, 1989). This is clearly the case at Monticello - a plantation and the home of Thomas Jefferson, one of founding fathers of the United States - as I came to know it from ethnographic observations of what in cultural studies is called "performance," or more prosaically, the ways visitors and the site's caretakers interact with one another, and from listening to what they say about such encounters. My ethnographic account is, however, truncated. I began observing Monticello when I went to work there as a "Visitor Services Specialist" from March 1988 to November 1988. I took notes of conversations I had with employees and visitors with an eye toward an ethnography of this American shrine. In 1989 Richard Handler and I wrote an article describing the dilemmas museums like Monticello and Colonial Williamsburg face as they attempt to enact contradictory egalitarian values in the ways they treat the visiting public. We also applied for funding to study these two institutions in depth. After reading our proposal and our paper, the leadership at Monticello decided that, because the museum was already "over-assessed,” our study would not serve its interests, and therefore denied our request to carry out research there. We went on to carry out fieldwork at Colonial Williamsburg exclusively. Nevertheless, Dr. Jordan, the current Director of the Foundation, agreed to be formally interviewed on two occasions in 1992. This essay combines elements from 
those interviews along with what I learned while I worked at Monticello and what I continued to learn in subsequent years from friends and acquaintances among Monticello's employees with whom I have stayed in close contact. It also includes what I have gathered from public sources. I should note that all quotes from conversations are from written notes I took at the time or from transcriptions of the tape-recorded conversations I had with Dr. Jordan.

When I started observing Monticello in 1988, I witnessed the beginnings of a major shift. The site's caretakers were compelled not only to tell the celebratory story of Jefferson's life and achievements, but also to represent slaves as historical actors in their own right; and they began to quietly change what they were willing to entertain about Sally Hemings, a mulatto slave who many Americans, and especially African-Americans, believed had a long-standing liaison with Thomas Jefferson. In early 1988 staff on the site were still treating this story as a myth not worthy of sustained discussion. By 1998 discussion of the liaison is a major theme in the site's verbal, textual and visual reconstruction of antebellum race relations. This ostensibly was because of a DNA study publicized in that year that showed the genetic connection between Jefferson and the descendents of Hemings (Foster; Tyler-Smith, 1998). But that study would never have been done were it not for what happened a few years before as African-Americans used the site to indict publicly the history of Monticello as a sham. I will focus on how the site's caretakers either were swayed by or dismissed public skepticism about the way the Foundation chose to deal with the purported liaison between Jefferson and Hemings. By looking at shifts in institutional policy on the liaison, I will illustrate the contested nature of official history in modern democracies, the way such contests are enacted in museum practice, and by extension what heritage does and does not do.

\section{The site}

Monticello is one of dozens of slave-era plantation houses which were bought in the first decades of the twentieth century by philanthropic organizations for the edification and enjoyment of the public (Peterson, 1960; West, 2001). But Monticello is a unique slave-era plantation because it was the residence of Thomas Jefferson; and the motto of the Foundation that runs the heritage site is to "preserve and maintain Monticello... as a national 
shrine and to perpetuate the memory of Thomas Jefferson and those principles for which he contended." "Those principles", guides at Monticello will tell you, are embodied in the three things for which Jefferson wanted to be remembered. He wrote Virginia's statute for religious freedom, he was the founder of the University of Virginia - one of the first publicly funded institutions of higher education whose core moral principles emerged out of enlightenment humanism rather than an association with a Christian faith and, above all, he was the author of The Declaration of Independence. It is from these three acts, and primarily for his authorship of the Declaration of Independence, that the Foundation - and to some extent the public adduces "those principles for which he contended". What is stressed is Jefferson's role as a founder of American political values - individual freedom, equality of opportunity, the pursuit of happiness.

The Foundation also stresses Jefferson's preoccupation with intellectual and aesthetic pleasure - his love of gadgets, art, literature, music, gardens, architecture, archeology, science, food. Indeed, the over half a million visitors a year who take a twenty-five minute tour of the house and spend perhaps an hour exploring the grounds are more likely to learn details of Jefferson's aesthetic interests than of his political principles. While in the house, they are treated to brief vignettes about mechanical wonders such as the Great Clock whose weights, one for each day, disappear into a hole cut into the floor. They are allowed a glimpse of the narrow stairways that lead to the "invisible" upper floors and the mysterious dome or "sky" room that none of the general public will ever see. But mainly there are books, paintings, musical instruments, furniture, wallpaper; and outside, flowers from around the world. Visitors receive a quintessential "house and garden" tour - with Jefferson playing invisible host.

At Monticello, Jefferson's pursuit of knowledge and aesthetic pleasures have been portrayed as both a sign of and a reward for his success at living a life according to the civic virtues he authored. Yet, because Thomas Jefferson was a slave-owner, this celebratory narrative has always been potentially threatened. Jefferson's particular freedom to pursue happiness for himself and his family could be linked to emiseration of others. Or Jefferson could be dismissed as a hypocrite whose lofty words did not match his deeds. Over the years I was familiar with Monticello, these criticisms occasionally surfaced in encounters the site's staff had with scholars in the wider knowledge-producing community. In these encounters historians and 
archaeologists suggested informally and privately that Monticello consider reconstructing slave quarters on the site to make it easier for visitors to experience Monticello as a "working plantation”. In the 1980s and 1990s the criticisms of Monticello and Jefferson crystallized in the popular imagination, around an illicit sexual liaison Thomas Jefferson allegedly had with a slave, Sally Hemings. That Jefferson denied having a long affair with an enslaved woman and denied any substantive connection to their several offspring could exemplify, at once, the typical hypocrisies of the politically powerful, the particular duplicities and fundamental inequities of race-based slavery, and - as "official history" continued to dismiss these stories - a sign of an ongoing cover-up.

\section{Interpreting a performance: defending Jefferson's reputation}

In 1988 when I began research at Monticello I was intrigued by the Foundation's response to visitors' often pointed interrogation of Jefferson's relationship with Sally Hemings. I was interested in how the ongoing act of representing a particular version of the past compelled a certain comportment among the site's caretakers and visitors alike. My assumption was that Monticello's ongoing conversation with its public would also entail teaching and learning a particular etiquette. This etiquette emerged out of the place museums typically occupy in modern democracies, the "exhibitionary complex", as Tony Bennett so deftly characterizes it.

To tease out the significance of museums in modernity, Bennett compares "the exhibitionary complex" (which includes art galleries, expositions and department stores as well as museums) to Foucault's "carceral archipelago" - the system of prisons, insane asylums and the like - which also has its origins in modernity. Prisons, Foucault famously argued, turned an opaque populace - thieves, murderers and other threats to public peace, hidden in the poor sections of the city or in the forests beyond the state's highways - into a visible and monitorable group. Museums, Bennett argues, made another populace into a citizenry - people who learned to look at the world through the eyes of power and as a result internalized that way of looking.

Not that the proprietors of increasingly open museums trusted their citizenry to behave themselves. Bennett reminds us that the rise of the modern museum arose from an ongoing conflict between reformers, 
emphasizing that the crowd can be educated not to be unruly, and elitists, ever fearful that the crowd will act like a mob, that they will touch and do damage to, rather than look. Because of this ambivalence about their public, Bennett notes, the democratizing museum inevitably fails to live up to an institution's own internally generated goals. The wish to "reform" is driven by two internally generated principles - "the first...sustaining the demand that museums should be open and accessible to all... the second... that museums should adequately represent the cultures and values of different sections of the public." These institutional imperatives lead to "insatiable" (that is never satisfied, but always crying out for satisfaction) demands for reform and endless talk (often self-serving) that reforms are occurring, that progress is, despite inevitable set-backs and obstacles, happening. Museums are supposed to be universal. If they are about "man”, they are about all groups of human-beings. Groups who feel excluded can make claims based on the museum's own morally binding goals - for inclusion (Bennett, 1995, p. 90).

Reforming museums claim, as Bennett puts it, to address a "public made up of formal equals” but end up making distinctions. The door is open, but not everyone seems willing to or proves capable of going through. If museums are places where a public learns to look but not touch, if they are sites where a public learns to become bourgeois, they are also places where caretakers come to assume as inevitable specific ways of governing or managing a public.

At Monticello I was particularly interested in what in museum parlance are called frontline employees - guides and other staff who convey the site's stories to the public. Guides, during the period of my research, tended to be middle-aged women of a certain cultured quality and education that would mark them as upper-middle class. There were also young men and women - recent graduates of university history and literature departments - barely scraping by on a meager guide's salary, and some of the older women were divorcees or in otherwise straitened circumstances, but they all maintained a cultured look and comportment. They were invariably "courteous" but they looked down their noses at such places as Colonial Williamsburg, where guides had to be artificially friendly to visitors and had to dress in period costume and speak in period accents. At Monticello, they dressed up rather than down. Their "uniform" was an idealized borrowing from the style of the country gentlewoman or gentleman. And when they retired from the public 
eye to have lunch together in the guides' kitchen, they ate meals that required a fork and knife or spoon, not sloppy sandwiches and the like. I found them congenial company. I wanted to ascertain how their encounters with the public led them to incorporate a certain lived attitude toward "the public".

To hear them talk, hardly a day went by when the site's guides were not asked by some visitor about "Sally Hemings", Jefferson's "slave mistress” or Jefferson's “other” (meaning unacknowledged) children. Often as not, the visitor would phrase the question in an accusatory or mocking tone - the kind of tone I associate with reporters at White-House press conferences when the event turns stonewalling into a kind of theater. And indeed, the guides' general response - the response their superiors encouraged them to make - sounded a lot like stonewalling. The guides I observed or talked with discounted the story as a kind of "rumor" by invoking the authority of "professional historians".

What they said emerged out of their appraisal of what motivated the public to ask such questions. But it also reflected what they had been taught. This is what they learned, for example, in the in-house compilation of frequently asked questions written specifically for guides, under the section, "What is the truth about Jefferson and the slave Sally Hemings?"

The allegation that Sally was Jefferson's mistress and bore his children was first published by a vengeful journalist... in 1802. Fawn Brodie’s biography of Jefferson and a novel by Barbara Chase-Riboud have recently reiterated this claim [(Brodie, 1974; Chase-Riboud, 1979)]. Although it is impossible to prove either side of the question, serious Jefferson scholars are unanimous in discounting the truth of such a liaison. In the opinion of Jefferson's biographer, Dumas Malone, it would have been totally out of character and “virtually unthinkable in a man of Jefferson's moral standards and habitual conduct”. (Stanton, 1987, p. 20).

The official position the guides were taught was ostensibly noncommittal - "impossible to prove either side of the question". Yet this training document juxtaposes the authority of "serious Jefferson scholars" with a "vengeful journalist", and a bestseller "novel" with the authority of Jefferson's most famous biographer.

So, it is not surprising that many of the guides interpreted visitors' persistent preoccupation with this sexual liaison as graphic evidence of the 
low appetite for scandal. As guides often put it, the public "wants to knock alabaster statues off their pedestals". Or the guides construed pestering queries as reflecting a barely concealed desire among the public to besmirch the Monticello Foundation's reputation. Guides often complained to me that aggressive if transparently sly questions such as "But what about Jefferson's other children?" made it "impossible", to do anything but react defensively. As one guide remarked, "a little while ago a visitor asked a guide (who had just finished her tour), 'what did you tell them about Thomas Jefferson screwing colored girls?' Now, how are you going to answer a question like that?" - without, the guide didn't need to add, becoming complicit in racial slurs or sexual crudities.

If an interest in discussing Sally Heming's sexual liaison with Jefferson was a sign of poor manners that could occasionally be dismissed as bigoted, some guides also believed that such questions also reflected a general, if misplaced, obsession with secrecy. Visitors often talked as if the upper floors of the house (especially the dome room), which are off limits to the general public, were secret chambers that contained important artifacts purposely kept hidden. People would get off the bus and want immediately to be directed to the "hidden" passages that they assumed honeycombed the house and grounds. These secret passageways and rooms were often associated in the popular imagination with Sally Hemings. Guides complained that visitors would occasionally pester them to show the "secret room" just above Jefferson's bed where Sally Hemings had remained hidden and waiting to answer his call. Some wanted the guides to show them the ingenious system of pulleys which allowed Jefferson to hoist his bed up into this secret cubby hole. Others asked to see the air tunnels they thought led to secret and distant locations for the love tryst. Usually such requests were countered with a courteous, if often icy, resort to a "just-the-facts" accounting. For example, those underground air-tunnels, they would tell the visitor, were "in fact" ingenious because they let fresh air circulate to privies situated close to the house. One guide remarked:

After one tour a woman came up to me and demanded to know why we didn't mention anything about the secret passageway to Michie's Tavern. I would like just once to wink or to give some sign...to pretend just once that the secret does exist, that the Foundation is part of some vast secret conspiracy to keep the truth from the people (but) because of some flash of communion with this particular visitor I'm going to lift the veil and reveal it all.

Horizontes Antropológicos, Porto Alegre, ano 11, n. 23, p. 51-70, jan/jun 2005 
As this guide saw it, visitors in pursuit of the secret of Sally Hemings were asserting the existence of a body of knowledge kept purposely out of the public domain. The guide also recognized that when she and her colleagues routinely dismissed the Hemings story as "fiction", or countered queries about the site's invisible passages and hidden chambers with a dry "just-the facts" response, they simply confirmed this suspicion.

In sum, guides learned the implicit lesson that in any democracy, no matter how open, there will always be a minority who believe in "conspiracy theories". Monticello was the perfect terrain upon which to enact such theories. Guides, who stood in an intermediary position between the public and museum leadership, developed an exaggerated faith in the truth of official knowledge as they found themselves compelled to act as guardians of the reputation of an exemplary figure and of the institution itself.

\section{African Americans and Monticello}

During the years that Monticello's guides were incessantly pestered by white visitors about Sally Hemings, the Foundation's leadership was trying to make the site more congenial to African Americans. The site's caretakers were embarrassed that there were so few black visitors to the mountaintop. The Foundation's director Daniel Jordan, the research historian Lucia Stanton, and the site's archeologist William Kelso all argued that if Monticello would focus more on the contributions of the hundreds of slaves who shared the mountaintop with Jefferson, then more African Americans would visit. In a 1992 interview, Jordan explained to me that for a long time "slavery was the "s' word" among the guides who preferred the less explicit euphemism "servants". In the Foundation's early days, members of the often implicitly segregationist "white identity" organizations - the "Daughters of the American Revolution" and the "United Daughters of the Confederacy" - served in rotation on Saturdays, Sundays and legal holidays, while black doormen in livery continued to greet tourists at the East Portico door. And gentility in whiteface continued to be a hallmark of the site long after these organizations ceased to have an official presence at Monticello.

To rectify the errors of the institution's past and to make the site more congenial to African-Americans, Jordon and his staff tried to represent slaves and slavery in the texts and images it produced. The Foundation also made efforts to reach out to the African-American community by inviting 
prominent African-Americans to speak at public events such as the July 4th naturalization ceremony. Most significantly, in 1992, the museum hosted a reunion of the Woodson family, whose members claimed to be descendants of Tom Woodson, the putative first and purposely unrecorded child of Thomas Jefferson and Sally Hemings. By looking at this event, we can see how Monticello, with its status as a site for the production of public history, could become a location for public contestation of that history, a contestation which is performed or enacted. During the reunion the Woodsons would question the official version of history to call attention to the generally disenfranchised status of African Americans in the national imagined community.

The Woodsons for their part insured that the event would be televised by NBC national news. There, the reunion was portrayed as an antagonistic encounter with the Hemings story resonating as a kind of exposé. The Woodson family, so the announcer said, came to Monticello "to claim what they say is their plantation". As such the Woodsons echoed what the political activist Jesse Jackson had said about Monticello on a visit that occurred shortly before the Woodsons made their appearance. Jackson accused Monticello of "throwing sand on the fires of history" because it failed to give credence to the love affair between Hemings and Jefferson or mention the offspring they created together. To Jackson (and to many other African American intellectuals), Monticello's squeamishness was symbolic of the inability of white America to accept black America as a part of the same over-arching national family. Like Jackson, the Woodsons asserted that Monticello had not been forthcoming in addressing their claims. Exposing miscegenation kept secret could be seen as central to telling a story of kinship denied.

The Woodsons, in short, portrayed Monticello as a typical white establishment villain. And every Monticello employee I talked to after the event agreed that the Foundation had taken a public relations beating on national television. Yet, Monticello did not expect the Woodsons to produce (with NBC's collusion) the generally derogatory sound-bites that would be broadcast to the nation. In an interview I had with Jordan several months before the event, he talked about the Woodson reunion with considerable enthusiasm - "a milestone in Monticello's dealing with this part of history". As he listed all the things Monticello was doing to focus more on slave life he exclaimed: 
I think a wonderful thing is going to happen next spring. That is, we believe we're going to have a reunion here of the descendants of some Monticello slaves... We participated in Black History Week this year and (our research historian) gave a wonderful talk...to a packed house...And she led them on a walk along Mulberry Row and explained to them what took place when, and how much we do know about these people - a lot. And this guy (who plans the Woodson reunion) was in the audience and has become a friend. And he mentioned the possibility of a reunion and I said, 'Gosh that's a wonderful idea.' So he's coming next week, and we're having lunch. And we're going to plan this homecoming and we're going to do everything that we can to see that it happens...

The homecoming Jordan envisaged was to have been a quiet one. The Woodsons would get a private tour of Monticello, the kind of tour the Foundation gives routinely to people they call "persons of stature" corporate and governmental VIPs, and the hundreds of Jefferson's legitimate descendants who hold their annual reunion at the family cemetery on Jefferson's birthday. The Woodsons would also be feted to a picnic lunch at the satellite plantation of Shadwell. But the discreet attempt at inclusion became, when the Woodsons invited the press, a public reenactment of exclusion.

Why then did the televised version of this event become an antagonistic encounter rather than the "homecoming" of new friends that Jordan portrayed himself anticipating in his interview with me? Initially I thought that it was because the Foundation was not aware of the Woodsons' genealogical claims. (Note that in the excerpt above the Woodsons are characterized as "the descendants of some Monticello slaves"). But in an interview after the visit, Jordan insisted that he knew all along about their putative ancestry. In that encounter I was impressed more than anything by his befuddlement with the public's continued preoccupation with the Sally Hemings story.

Jordan remarked that "Jefferson", (like the Foundation), "would never duck any tough questions like race. But, on the other hand he's a man for the ages... and we don't want to be too provincial in this stewardship."And in some sense his status as slaveholder might count as a provincial issue, an issue that associated Monticello with "the South", as compared to, for example, his authorship of the Declaration of Independence, an achievement of global significance. 
But just as importantly, Jordan simply believed that "serious scholars" were similarly dismissive of the issue. He reminded me that the historian John Chester Miller, who had often been a critic of Jefferson the slaveholder, and who had also privately criticized Monticello's treatment of the topic of slavery (he had been a "friendly gadfly" as one staff member put it to me) "wrote a whole chapter demolishing the liaison". But he also noted that "Monticello sells more copies of Fawn Brodie than any bookstore in America." Jordan was referring to the bestselling work of "psychological history" that went a long way in publicizing the liaison as "fact," and that the Foundation explicitly dismissed as unsubstantiated guesswork. Jordan made this remark to emphasize that Monticello was tolerant of a diversity of opinions. But he stressed that Monticello did not modify the way it responded to the public's interest in the Hemings story either in reaction to criticism or in response to consumer preference. He said that if there were ever hard evidence of the liaison, then the Foundation would tell the truth no matter how controversial, but "right now, we just don't know". Nevertheless, in discussing the Woodson family's claims, he wanted to be sure that I knew that, "I respect their oral tradition".

\section{Where the truth lies}

To respect an oral tradition while at the same time maintaining a judicious "agnosticism" (as it is often described by historians writing on the topic) on the issue of the liaison entailed a peculiar construction of an official community of memory at the site. It privileged, if inadvertently, a certain kind of "serious scholarship" as standing for the final word as far as "professional knowledge" is concerned; it allowed for contestation of that knowledge, but only as that knowledge is subtly marked as different, "other", "oral" traditions passed down through the generations as a kind of collective memory among "other” people. ${ }^{1}$

1 It is instructive to compare white and black historians before the DNA evidence made it harder not to conclude that Jefferson and Hemings had a long sexual liaison. Joseph, J. Ellis (1997), while claiming to a certain agnosticism on the topic, concluded that "within the scholarly world and especially within the community of Jefferson specialists, there seems to be clear consensus that the story is almost certainly not true. Within the much murkier world of popular opinion, especially within the black community, the story seems to have achieved the status of self-evident truth" (Ellis, 1997, p. 303). Ellis counts himself as a member of 
New evidence of the officially recognized kind was, however, eventually produced, in large measure because the Woodsons continued to press their claim, provoking a collection of DNA from themselves, other Hemings descendents, and descendents of Thomas Jefferson's "white" family. When the journal Nature published an analysis the DNA evidence (along with an editorial by the historian Joseph Ellis, who compared Thomas Jefferson's sexual transgressions to President Clinton's with Monica Lewinsky) in November 1998, Dr. Jordon (who knew about the article in advance) immediately held a news conference to accept the report as the truth. What Jordon did not address in that news conference was the fate of the Woodson family's claim to a connection to Jefferson, a claim which, ironically, was also ostensibly disproved by the same DNA evidence that proved the Hemings-Jefferson liaison. In the months following, the Woodsons would complain loudly to who ever listened that they trusted the DNA evidence as little as they had once trusted those who had relegated their memory to the status of rumor. As a result of their complaining, as much as because of the DNA results, the Woodsons would also quickly lose their cachet at Monticello.

I witnessed the last public occasion that the Woodson descendents would be invited to the site. Scholars were presenting evaluations of Monticello's role in remaking the American imagined community, in effecting, as one of the panelists, the director of Monticello's guides, put it, "healing" between blacks and whites. Now that Sally Hemings had taken her place alongside Thomas Jefferson, black and white Americans could recognize that they were a single "family". By accepting the truth of the DNA tests, Monticello had become a locus of racial reconciliation.

Then Byron Woodson spoke. His story was more critical than celebratory. He argued that the DNA test had been "hijacked" by Clinton supporters to "save his presidency" by comparing Clinton's peccadilloes with Monica Lewinsky to Jefferson's liaison with Hemings. Byron Woodson

what he calls "the scholarly world" because for him too the "likelihood of a liaison is remote” (Ellis, 1997, p. 303). The African American legal scholar Annette Gordan-Reed's (1997) brilliant and meticulously argued case for Jefferson's paternity should be read as Ellis' opposite. It is a generally accepted argument among African-American intellectuals and historians that Jefferson's liaison was a fact and its cover-up a signal example of the more general tendency in the white community to deny such relationships. Indeed, it could be argued that such a history of denial is at the root of the invention and maintenance of distinct racial categories in America. 
emphasized that this kind of hijacking of black history for white purposes "has been going on for too long" and was still going on. Later, Byron Woodson would publish a book, A President in the Family: Thomas Jefferson, Sally Hemings, and Thomas Woodson (Woodson, 2001). In it he would make several accusations of cover-up, and concluding with a critique of the duplicities of official history:

Ultimately, however, the Hemings/Jefferson controversy will not be resolved... with a bogus headline in Nature, not in a press conference called by the Thomas Jefferson Memorial Foundation... It will be resolved by a family - my family. (Woodson, 2001, p. 251).

\section{Conclusion}

When scholars study history museums to see what they do to the identities of publics that visit them they usually treat the site as a collage of texts to be read as "representations" of the ideology of official history. But we can also consider the museum as a kind of theatre where guides and visitors alike perform. Such performances can be interpreted for what they tell us about making citizens, about making publics in democracies - about how identity as an act. In the first approach a history museum produces the ideas about the past that an "imagined community" holds (more or less) in common. In the second approach, the museum produces a certain kind of comportment which can be resisted or contested. It is this second methodological approach that I have employed here. What can we learn from the two sets of performances I have sketched above - first, the day to day encounters that occurred between guides and visitors, and second, a dramatic event involving African American appropriations of the site?

Above all, it is clear that official history is being constantly questioned. When the members of the Woodson family stand on Mulberry Row and complain to Monticello's chief research historian that their tour has been a "glaring disappointment" because their ancestor, Tom Woodson, was not mentioned along with Jefferson's other children, they are questioning the official terrain at Monticello. When visitors ask the niggling question about Sally Hemings, they, too, are subverting official history. Some of these, doubtless, want their suspicions confirmed that in things American there is always a conspiracy afoot. Others probably get a certain bigoted pleasure 
in being able to assert in public that even the sanctimonious are "screwing colored girls". Such questioning has a variety of effects, among them that Monticello has been able to dismiss much public criticism as evidence of public inferiority, a symptom of a more pervasive ignorance among the masses at large. As such, the performative space of Monticello confirms a fairly standard (and secretly cynical) attitude "experts” in democracies have about the public in general. They are ignorant, so they need guidance.

But occasionally public criticism has to be taken more seriously. If white visitors could be dismissed for believing in the liaison between Sally Hemings and Jefferson, black visitors could not so easily be shrugged off, precisely because their absence from the site was itself an indictment of its democratic pretensions. Yet, such efforts can also be interpreted by a cynical public (and cynical insiders as well) as no more than a public relations ploy. After the news conference in which Dr. Jordon accepted the DNA evidence a member of Monticello's staff would remark privately to me that the news allowed for a public relations windfall because, out of the hundreds of articles that were in the national press, most would remark favorably about Monticello's admirable lack of defensiveness in accepting with alacrity the verdict of science on an old and festering controversy.

Caretakers at Monticello cannot help but want to celebrate their own impartiality and to downplay the contested nature of history itself, even in the face of clear evidence to the contrary. A vernacular skepticism about the motives and truth of public history results. In the vernacular view, official history will always be a whitewash. Like the Stalinist history Milan Kundera exposes in The Book of Laughter and Forgetting, an official narrative is a photograph out of which the purged politico has been airbrushed. That Monticello produces official history in this pejorative sense is what many of Monticello's visitors persist in believing, even as the Foundation attempts to be more inclusive and more attentive to the sensitivities and demands of hitherto ignored constituencies. This, in the end, is the lesson the Woodsons learned. One imagines that their experience continues to exemplify what many African Americans believe about sites such as Monticello.

What can museum professionals do about this? Will they ever be able to produce a past that makes for a more inclusive community of memory, a past that would create and maintain a more cohesive identity? I would argue that the solution lies in a much more radical form of honesty than is current practice at Monticello and places like it. Monticello needs ultimately 
to convey its past complicities in history's inevitable erasures. To Jordon and other caretakers of Monticello, the landscape they preside over is a more or less accurate if partial facsimile of the truth. They strive, they constantly assert, to make a hitherto hidden landscape more visible, truer, as they sift through the evidence and listen to the testimony of experts. But they also want "the public" to applaud their efforts - to trust them as "stewards", as Jordon put it to me, of a collective past. This requires an inevitable erasure which is far more subtle than the crude airbrushing of totalitarian regimes. At Monticello, this erasure entails purging from the public memory of the site, not only the profundity of disagreements among the public about what counts as history (whether slavery or the Declaration of Independence is the more important story), but the contested nature of history making itself (which is never as disinterested and objective as Jordon's acceptance of the fait accompli of the DNA evidence would make it appear) in favor of commemorating its calculated objectivity. As a result, Monticello, perhaps because of its desire for consensus, ends up producing two parallel landscapes that together add up to the terrain of modern democracy: a visible landscape of shared knowledge without controversy or conflict, and an invisible landscape of suspicion, mistrust, and paranoia.

\section{References}

ANDERSON, B. Imagined communities: reflections on the origin and spread of nationalism. Verso: New York, 1991.

BELLAH, R. et al. Habits of the heart: individualism and commitment in American life. Berkeley: University of California Press, 1985.

BENNETT, T. The birth of the museum: history, theory, politics. New York: Routledge, 1995.

BLATTI, J. (Ed.). Past meets present: essays about historic interpretation and public audiences. Washington D.C.: Smithsonian Institution Press, 1987. BRODIE, F. Thomas Jefferson: an intimate history. New York: W.W. Norton, 1974.

CHASE-RIBOUD, B. Sally Hemings. New York: St. Martins Press, 1979. ELLIS, J. J. American sphinx: the character of Thomas Jefferson. New York: Alfred A. Knopf, 1997. 
EVANS, J.; BOSWELL, D. (Ed.). Representing the nation: a reader: histories, heritage, and museums. London: Routledge, 1999.

FOSTER, E. A.; TYLER-SMITH, C. Jefferson fathered slave's last child. Nature, p. 27-28, Nov. 5, 1998.

GABLE, E. Making a public to remake the past at Colonial Williamsburg. Museum Anthropology, 21, n. 2, p. 1-13, 1997.

GORDON-REED, A. Thomas Jefferson and Sally Hemings: an American controversy. Charlottesville: University of Virginia Press, 1997.

HANDLER, R.; GABLE, Eric. The new history in an old museum: representing the past at Colonial Williamsburg. Durham: Duke University Press, 1997.

HORTON, James Oliver; CREW, Spencer R. Afro-Americans and Museums: towards a policy of inclusion. In: LEON, Warren; ROSENZWEIG, Roy (Ed.). History museums in the United States: a critical assessment. Urbana: University of Illinois Press, 1989. p. 215-236. KAMMEN, Michael. In the past lane: historical perspectives on American culture. New York: Oxford University Press, 1997.

KARP, I.; LAVINE, S. D. (Ed.). Exhibiting cultures: the poetics and politics of museum displays. Washington D. C.: Smithsonian Institution Press, 1991.

KARP, I.; KRAEMER, C.; LAVINE, S. D. Lavine (Ed.). Museums and communities: the politics of public culture. Washington D.C.: Smithsonian Institution Press, 1992.

KURIN, R. Reflections of a culture broker: a view from the Smithsonian. Washington D.C: Smithsonian Institution Press, 1997.

LOWENTHAL, D. The past is a foreign country. New York: Cambridge University Press, 1985.

MILLER, J. C. The wolf by the ears: Thomas Jefferson and slavery. Charlottesville: University of Virginia Press, 1977.

NANDA, Serenda. South African museums and the creation of a national identity. American Anthropologist, 106, n. 2, p. 379-385, 2004.

PETERSON, M. The Jefferson image in the American mind. New York: Oxford University Press, 1960. 
SHERMAN, Daniel; ROGOFF, I. (Ed.). Museum culture: histories, discourses, spectacles. Minneapolis: University of Minnesota Press, 1994. STANTON, L. Monticello: facts and figures. Charlottesville: Thomas Jefferson Memorial Foundation, 1987.

WEST, P. Domesticating history: the political origins of America's house museums. Washington D.C.: Smithsonian Institution Press, 2001.

WHITE, G. M. Introduction: public history and national narrative. Museum Anthropology, 21, n. 1, p. 3-7, 1997.

WOODSON, B. W. A president in the family: Thomas Jefferson, Sally Hemings and Thomas Woodson. Westport: Praeger, 2001.

YELVINGTON, K. History, memory and identity: a programmatic proglemenon. Critique of Anthropology, 22, n. 3, p. 227-256, 2002. 